\title{
SOCIO-ECONOMIC SCENARIO OF THE RURAL STONE CRUSHERS OF SILIGURI BALASON RIVER BASIN
}

\author{
Arindom Biswas \\ Assistant Professor, Department of Geography, \\ Dumkal College, Murshidabad, West Bengal, India \\ Email-biswas.arindom@gmail.com
}

\begin{abstract}
The present study attempts to find out the socio-economic condition of the rural stone crushers of Siliguri Balason river basin. The river Balason near Siliguri transmits the natural resources like stone, sand and boulders. People live on the water's edge and are involved in work like collection of stones and sand, crushing the stones into different shapes and sizes and loading them into vehicles. While most of the rural inhabitants make their way to the fields as expected in the countryside, residents in Balason river colony, welcome every day of the year trekking uphill the Balason stone quarry. Men, women with children on their backs, start and end their entire day extracting, lifting and crushing stones; using easy handmade tools to quench the insatiable construction industry in the rapidly urbanising city. As one of the units of informal sector, the stone crushers has been significantly contributing in strengthen the small scale economic sector. But the study extremely found that the Stone crushing industry have a regressive and insignificant impact on socio-economic conditions of workers due to low wages, lack of working and welfare measures and environment. Accordingly, the study intended some policy implications to balance the existence of Stone Crushing Units, employee's welfare and environment protection.
\end{abstract}

Key words: Stone Crushers, Construction and Crushing industry, Environment protection.

\section{Introduction}

Agricultural activities and mineral extraction are playing a vital role in rural livelihood improvement thereby helping to alleviate rural poverty. In developing countries like India many people are engage in occupations such as small-scale surface mining and quarrying for their survival. Mining plays a significant role in the development of human societies. The mining of minerals, stones and coal etc. have provided a foundation for local economies in many parts of our country. Stone crushing industry in India is an unorganized small-scale sector and basically a labor intensive small scale industry, where most of the procedures are performed manually. Most of the plant and machinery has been conventional type in nature and made-up locally. It is one of the sources of earning for uneducated poor unskilled rural people. In this economic sector many people are engaged in producing crushed stone of various sizes depending upon the local demand which acts as raw material use for various construction activities like as construction of houses, roads, National Highways, Bridges, Office Buildings, and multipurpose water canals etc.

As one of the units of informal sector, the stone crushers has been significantly contributing in strengthen the small scale economic sector. Stone quarrying is one of the key economic activities in the Siliguri Balason river basin area, supplying the bulk of stone of varying aggregates to the construction industry within the district and beyond. It has been proved very efficient in strengthening the local economic condition. As per records of to the Survey of India Topographical Map the stone crushing activities along the Balason River 
stated when the river shifted its course into the present position, which previously used to be a good fertile agricultural land with moderate forest cover. The loss of agriculture lands local people is forced to involved in quarrying of the stone materials as an alternative source of income. Since 1980 the quarrying activity permitted by the govt. and basin area leases were distributed to the local landholders.

\section{Objectives of the Study}

The objectives of the present study may be summarized in the following lines:

- To find out why people engage in stone quarrying in Balason river area.

- To find out the outcomes of small scale stone quarrying activities in study area.

- To assessing the effects of processes, institutions and govt. policies on stone quarrying in Balason river basin.

- To find out the livelihood conditions of rural stone crushers in the study area.

\section{Materials and Methods}

The present study was focused on people of working in stone crusher industry. This study was carried out among the workers of the stone crushers located in Balason river basin in Siliguri city of North Bengal. Stratified random sampling method is used in the present study and employing both quantitative and qualitative techniques. Various books, journals, newspaper and articles have been widely reviewed to construct the framework of the study. The total selected respondents are 138 and total 35 households have selected for the study. Primary data from households is collected through rigorous field survey of Balason river basin area and direct interaction with the quarry workers with the help of semistructured questionnaire schedule which included questions regarding age, sex, educational status, socio-economic status, duration of stone crusher activities, health conditions and different environmental aspects. In depth verbal interviews and focus group discussion have been done to acquire qualitative primary data. Trust worthy informants have picked up from each households. The required secondary data takes from various Journals, Newspapers, District abstracts, Census of India records and concerned departments also. The data collected was statistically treated, using statistical software SPSS and various cartographical representations.

\section{Study Area}

Siliguri town located at the foothills of the Eastern Himalayas at a location of $26.71^{\circ} \mathrm{N}$ $88.43^{\circ} \mathrm{E}$. The city is bounded by dense forests towards north and lifeline of Siliguri, Mahananda River flows through the city thereby dividing it into two-halves. Being the major right bank tributary of the Mahananda River, Balason originates from Lepchajagat and it joins the Mahananda River near Siliguri town. The Balason River passes between the valley of Pokhriabong, Dhotreia, Nagari Fram, Moonda Kotee, and Ambootia Tea estate of West Bengal. Balason is a perennial river with a basin area of $367.42 \mathrm{~km}$ and a length of $48.40 \mathrm{~km}$.

\section{Socio-Economic Scenario of Rural Stone Crushers}

Many Economists and Geographers agreed that livelihood strategies as activities that generate the means of household survival. These approaches were determined by available assets and the external environment. Near about 40 years ago some migrants people were started to settle down on the Balason river bed by establishing a colony named as 'Balason colony'. They unquestionably choose the stone crushing work for the primary requirements of their existence since it demands only manual labour without any kind of capital investment. This occupation provided them a settlement on the river bed and at the same time a new source of income. 


\section{Age Structure}

Stone quarrying not any different from other informal activities engages all groups and both gender. From the interviewed respondents, findings showed that the age group distribution of stone crushers in the study area is shown in the table no. 1. The age of the workers may influence their working and production capacity. Age forms one of the important determining factor in understanding the observations, attitudes and working capacity of the stone crushers.

Table 01: Age Structure of the Respondents

\begin{tabular}{|l|c|c|}
\hline Age Group & No. of Respondents & Percent \\
\hline Below 20 & 29 & 21.01 \\
\hline $21-40$ & 61 & 44.20 \\
\hline $41-60$ & 35 & 25.36 \\
\hline Above 60 & 13 & 09.43 \\
\hline Total & $\mathbf{1 3 8}$ & $\mathbf{1 0 0}$ \\
\hline
\end{tabular}

Source: Field Survey. 2019

Figure 01: Age Structure of the Respondents

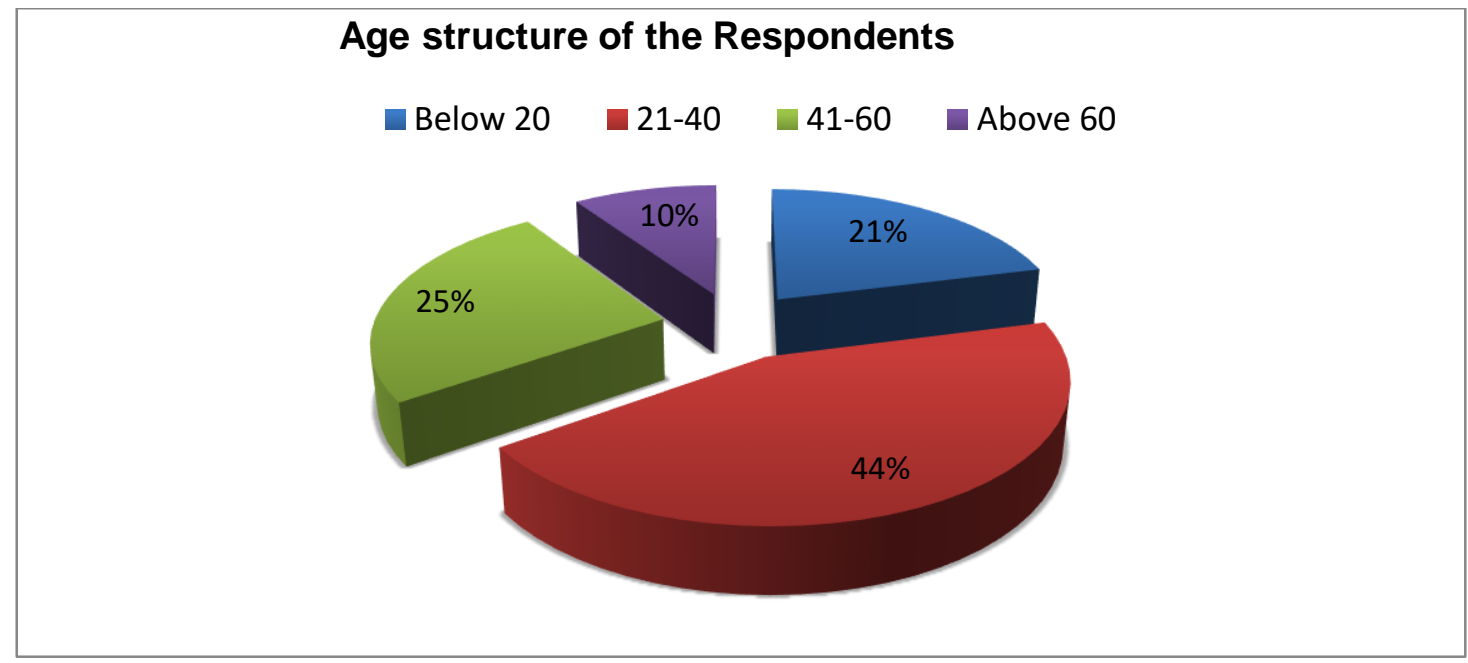

In developing country like India stone quarrying not any different from other informal activities engages all groups and both gender. From the interviewed respondents, outcomes showed that 21.01 percent of the sampled respondents were aged below 20 years. Those between 21-40 years comprised 44.20 percent while those ages between 41 60 years were 25 percent. Remarkably, the percentage of respondents declined with increase in age above 40 years. It shows that only 9.43 percent workers are engaged with stone quarrying activity whose age is above 60 . The use of simple tools to extract hard rock material from river bed makes stone quarrying a strenuous activity.

\section{Gender Composition}

From the interviewed families and respondent's data shows that stone quarrying activities involved mostly men who comprised 65 percent while the women were 35 percent. The ratio of women to men is also related to intensive activities engaged in stone quarrying. Participation rate of women workers in the quarrying activities along with their male counter parts is significant in the study area because of their feminine nature are engaged in stone quarrying activities which were less straining and less paying as well. But women's attendance at the quarry was irregular at because they had to attend to domestic chores which involved their reproductive roles such as child bearing, child rearing and taking care of household responsibilities. 
Table 02: Gender Composition of the Respondents

\begin{tabular}{|c|c|c|c|}
\hline No. of Families & Male Workers & Female Workers & Total Respondents \\
\hline 35 & 90 & 48 & 138 \\
\hline Percentage & 65.21 & 34.79 & 100 \\
\hline
\end{tabular}

Source: Field Survey, 2019

\section{Educational Status}

Education is recognized as one of the important constituents of human resource development. Education is an important determining factor in securing employment opportunities in the formal sector. But in Balason river basin area colony the status of education and awareness is very poor among the stone crusher workers and their families. The percentage of literacy is comparatively low among the worker's families.

Table 03: Educational status of the Respondents

\begin{tabular}{|l|c|c|}
\hline Educational Qualifications & No. of Respondents & Percent \\
\hline Illiterate & 39 & 28.26 \\
\hline Primary & 57 & 41.30 \\
\hline Secondary & 33 & 23.91 \\
\hline Higher secondary and above & 09 & 06.53 \\
\hline Total & 138 & 100 \\
\hline
\end{tabular}

Source: Field Survey, 2019

The data involving to the educational background of the stone crushers is collected in the field survey and is grouped into four categories and the same has been represented in the table no. 3. As shown in table no. 3, 28.26 percent of the sampled workers never had any formal education, 41.30 percent dropped out at the elementary level of primary education, while 23.91 percent attended secondary school and only 6.53 percent attended higher secondary and above institutions. To these worker's poverty was associated with lack of adequate basic elementary education. The stone crusher workers justified their low education status with their presence at the quarry.

\section{Economic Conditions and Level of Income}

The economic condition of the workers of Balason river basin area are classified in to four categories basing on their monthly income levels and presented in table no. 4. It is concluded from the table that 11.42 percent of the workers are income under or below Rs 5000 income group followed by 28.55 percent in Rs. 5000-10000 income group and 25.72 percent are under income group of Rs. 10000-15000 and rest of families' 34.29 percent income are above Rs 15000 as per the study of survey report.

Table 04: Economic Condition of the Respondent Families

\begin{tabular}{|c|c|c|}
\hline Monthly Income & No. of Families & Percent \\
\hline Below 5000 & 04 & 11.42 \\
\hline $5000-10000$ & 10 & 28.57 \\
\hline $10000-15000$ & 09 & 25.72 \\
\hline Above 15000 & 12 & 34.29 \\
\hline Total & 35 & 100 \\
\hline
\end{tabular}

Source: Field Survey. 2019

The stone crushers workers are not at all paid proper remuneration for their hard work. The monthly income of the families is very low as shows in the above table. The stone based workers worked under a manager called "sardars". The sardars paid them money either daily or weekly basis. On an average, the monthly income of the workers is more or less, Rs 10 thousand only. This meagre amount is not enough to attain at least comforts. More number of respondents of this area is placed in the income group of Rs 10 
thousand and above. Nearly 50 percent of the respondents are losing Rs.200-500 per month as wage loss due to ill health. Workers are losing 3-4 days' job due to ill health in some weeks. They are suffering wage loss during slack season, rainy and flood condition of Balason River. Poverty and unhappiness were an integrated part of their life. These factors had raised other serious problems simultaneously.

Figure 02: Economic Condition of the Respondent Families

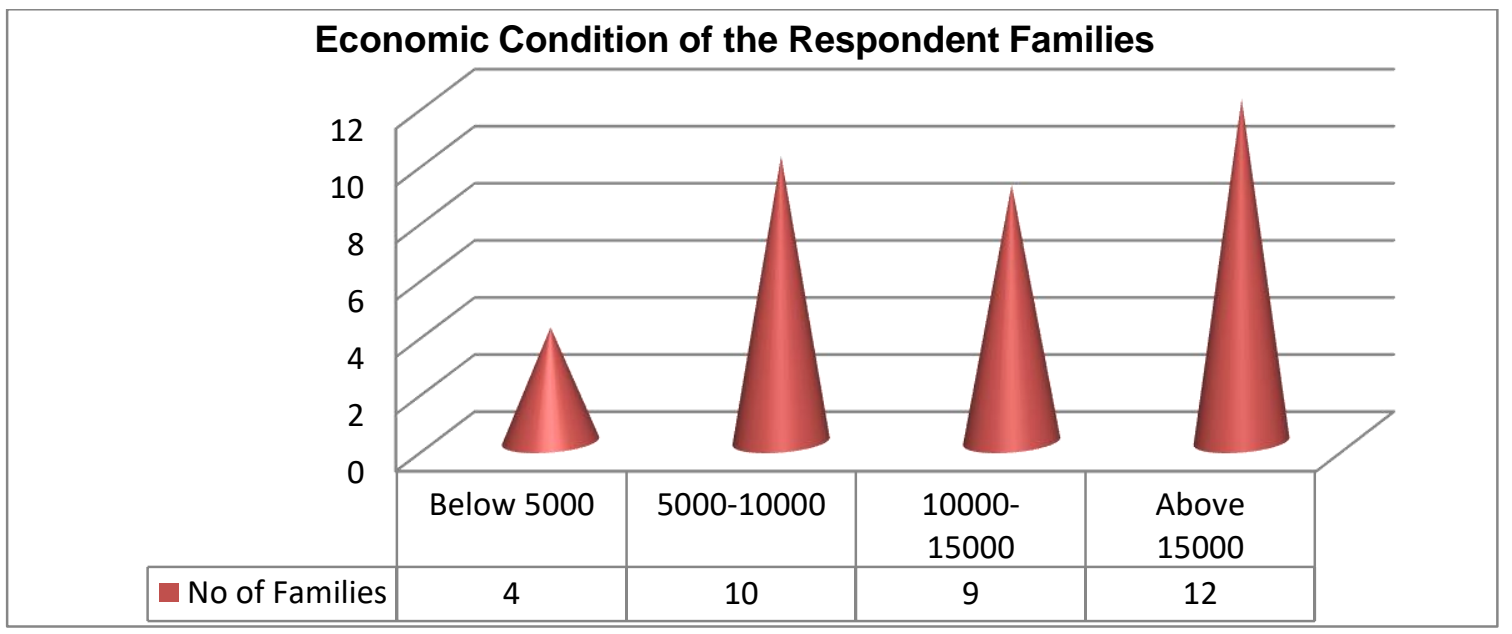

It is observed in the Balason area that the lack of assets to initiate personal businesses was noted as a contributory factor to engaging in stone quarrying activities. Some of the stone crushing workers especially women and the youth aimed at accumulating financial capital in order to buy productive assets such as land for agricultural production, construct houses for rental purposes or living, or buy a motorcycle, auto rickshaw or electric vehicle to engage in the urban transport industry. These workers lamented that stone quarrying activities was quite difficult for one to be involved for a long time.

\section{Health Conditions}

Quarrying activities in Balason area have negative effects on the health condition of the people living in and around the area, the workers at the quarry companies as well as the small-scale stone quarry operators. Stone quarrying degrades the environmental condition with dire consequences on human health. Due to poor economic infrastructure in this area the physical setting of the houses is poor and devoid of basic amenities of sufficient room and drainage systems. As a result, the houses are the key birth place of germs and generating a number of diseases. As many as worker's injuries their hands, legs and on other parts of their body caused to manual stone cutting, blasting activities without enough care in the working area. The cut pieces of stones hit the worker with great force and cause the wound. Apart from the above organs eyes are more unprotected to stone dust and small pieces of stones. The lack of provision of spectacles by the owners making workers' conditions miserable. Noise levels are more and consistent in and around the Stone Crushing sites of Balason river basin area. Continuous exposure to blasting, cutting, loading/unloading activities, aggravate the health problems especially ear problems of the workers in Balason river basin area.

\section{Living Conditions}

All the workers of Balason river basin are living in Slums and near Balason colony in very poor condition. They do not have even minimum facilities like safe drinking water, drainage, healthy latrines and the surroundings seems to be very dirty. Only few families have had govt. water and the others taking unsafe and polluted water resources, as a result stone crusher workers suffering with water borne diseases as accepted the fact by the concerned local Health Officials. Due to absence of housing facilities and lack of income to pay for 
transport these workers choose to live near to basin area or stone cutting work sites. They are live in very small unprotected thatched houses.

\section{Major Outcomes of the Study}

The socio economic condition of stone crushers of Balason river basin has explored the different livelihood outcomes as a result of stone quarrying at individual, household and communal level. These major outcomes are as follows:

- The study shows that with an increase in income, the workers provided their families' needs and at the same time obtained assets (human, physical and natural) that they desired. Other livelihood outcomes noted were improved self-esteem, increased social capital which wasn't only important in increasing productivity but was used as a coping approach by the workers during shocks.

- Stone quarrying activities at Balason river basin was unregulated with easy entry and it involved labour intensive activities coupled with low technology and working skills. The use of indigenous resources coupled with productivity on a small scale and depicted characteristics of the informal sector of economy.

- The study revealed that most of the workers who have work in stone crusher units of Balason river basin are related to rural and economically backward areas where employment opportunities and agricultural activities are limited and therefore it carries greater significance in terms of socio-economic importance in surroundings of Siliguri town and local rural areas. It is one of the easy sources of earning for the uneducated poor unskilled rural people.

- Increase in income increases one's well-being in terms of health, education and general contentment. The stone crusher workers identified the different ways money enabled them realize other benefits. They were able to provide for their household with basic needs and invest in assets such as; land, houses and also retail business.

- In other ways the physical observations made in the sample area reveal that many of stone crusher workers have low life expectancy even lower to country's average. Everyday road accidents are taking place at near the stone crushing units but no complaint was lodged on the grounds of reduced visibility, in the Balason river basin area.

- There was evident loss of biodiversity as workers cleared river bed materials to expose the rock material for extraction. As the workers burnt tyres to enhance rock expansion there was production of dust and smoke from burning rubber which was a health hazard both to the workers and the surrounding community in Balason colony area.

- The study revealed that quarrying activities also contributed to the growth of infrastructure such as roads, increased migrant settlement and social services such as schools and health centre in Balason colony. Other income generating activities have also resulted because of stone quarrying in the river basin area.

\section{Conclusion}

In India informal sector is one of the major sources of employment opportunities. But with insufficient financial capital and easy hand-made tools small scale stone quarrying doesn't generate returns to commensurate the efforts and time expended. Consequently, income from the sector is terribly low. Here in Balason river basin area crushing stone industry is one of the informal sectors which possible to establish at lower cost of production and contribute significantly in developing modern infrastructure of Siliguri town and other adjacent area. Stone quarrying activities also enriched the capabilities of the rural poor and 
the migrant working population. In addition to improved wellbeing, the workers were able to be adequately nourished, improve their health and lead a life without humiliation. Small scale stone quarrying enhances the expansion of other livelihoods both within the community and within the stone workers' home town. Because such activities are fast profit yielding, they'll be used as a basis to reinforce rural development, since they promote infrastructural development. But in the environmental context to ensure the sustainable development, there is need to recognise informal economic activities such as stone quarrying by policy makers and NGOs. This is relation to reducing shocks that affect the livelihoods as well as those engaged in them. In the same way, environmental sustainability should be given a high priority in an effort to preserve finite resources for the future generations.

\section{References}

1. Asante F, Abass K, Afriyie K. Stone quarrying and livelihood transformation in PeriUrban Kumasi. Res. Human. Social Sci. 2014; 4(13): 93-107.

2. Brajesh, J. (2006). Rural Non-Farm Employment in India: Macro-trends, Microevidences and Policy Options. IEG Working Paper Series No. E/272/2006

3. Chauhan SS. Mining, development and environment: a case study of Bijolia mining area in Rajasthan, India. J. Hum Ecol. 2010; 31(1): 65-72.

4. CPCB (2009); Comprehensive Industry Document Series on Stone Crushers: COINDS/78/2007-08. www.cpcb.nic.in.

5. De Haan, A. (2002). Migration and Livelihoods in Historical Perspective: a case study of Bihar, India. Journal of Development Studies 38 (5): 115-42

6. Ellis, F. (2000) Rural Livelihoods and Diversity in Developing Countries. Oxford University: New York Press Inc.

7. Lahiri-Dutt K. Digging to survive: women's livelihoods in south Asia's small mines and quarries, South Asian Sur. 2008; 15(2): 217-244.

8. Lahiri-Dutt K. Not a small job: stone quarrying and women workers in the Rajmahal traps in Eastern India, 2003; [Online]. 2019

9. Lanjuow, P. \& Abusaleh, S. (2004). Rural Non-Farm Employment in India: Access, Income and Poverty Impact. Working Paper, Economic and Political Institute, India.

10. Sinha RK, Pandey DK, Sinha AK. (2000): Mining and the environment: a case study from Bijolia quarrying site in Rajasthan, India, The Environmentalist. 195-203.

11. The Stone Quarrying Industry around Delhi- Impact on Workers and the Environment, www.apfed.net. 